UDC [616.98:578.835.12:579.842.15] - 053.2 - 078:612.017.1

DOI: $10.15587 / 2519-4798.2017 .104687$

\title{
ALTERATION OF BLOOD CYTOKINE CONTENT AT SHIGELLOSIS IN CHILDREN WITH HELICOBACTER INFECTION
}

\begin{abstract}
(C) N. Kurlan
У дослідженні представлені результати оцінки вмісту про- та протизапальних інтерлейкінів сироватки крові дітей, хворих на шигельоз та інфікованих Н.руlогі. Отримані дані відображають суттєвий вплив інфікування H. pylori на показники вмісту цзитокінів крові хворих на шигельоз як в гострому періоді, так $i$ на етапах ранньої реконвалесцениії, та можуть бути використані для подальшого вдосконалення терапії таких хворих
\end{abstract}

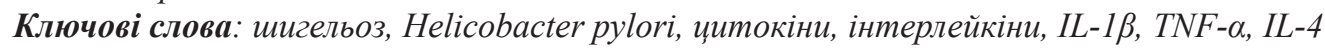

\section{Introduction}

Acute enteric infection rate in children is high up to the present day $[1,2]$. According to the data provided by the World Health Organization, over the last years viral diarrhea is considered to be prevailing in the structure of acute enteric infection. However, the rate of bacterial pathogens, Shigella in particular, among the causative agents of infectious diarrhea is still high [2, 3].

The course of shigellosis and its consequences are known to depend on balanced action of pro-inflammatory and anti-inflammatory interleukins (IL) characterized by highly comprehensive functional activity. They are primary mediators of pro and anti-inflammatory immune responses, stimulators for formation and release of a range of other secondary mediators; its number in blood dramatically increases in patients in case of inflammation, consequently plasmatic levels of interleukins can serve as prognostic criteria of diseases outcome [4]. At the same time, over time action of such proinflammatory cytokines as TNF- $\alpha$, IL- $1 \beta$ and IL-4, which control formation of local inflammatory reaction and system clinical manifestations, reflects macroorganism's resistance level to some extent, which in its turn influences the course of disease $[4,5]$.

The combined action and balance between proinflammatory (TNF- $\alpha$, IL-1 $\beta$ and others) and anti-inflammatory cytokines effects are supposed to be critical for development and outcome of infection process as well as to influence its severity and long-term prognosis. In other words, they play a significant role in immunopathogenesis of the disease and the concentration of them in blood serum reflects immune reactions which occur locally and/or in a consistent manner $[6,7]$. A combination of actions and balance between effects of pro-inflammatory and anti-inflammatory cytokines are considered to be critical for development and realization of infection process [7].

IL- $1 \beta$ is a pro-inflammatory cytokine stimulating local and system response. It is a key element in development and regulation of non-specific protection and specific immunity as well as it is the first to be involved into protective reaction of the body under action of pathogenic factors $[6,8]$. IL-1 $\beta$ initiates and regulates inflammatory, immune processes, activates neutrophils,
T- and B-lymphocytes, stimulates the synthesis of acute phase proteins, other cytokines (IL-2, 3, 6, TNF- $\alpha$ ), adhesion molecules, procoagulants, prostaglandins. IL-1 $\beta$ system effects include hypotension, fever, neutrocytosis, thrombocytosis and production of acute phase proteins [9]. Multifunctional pro-inflammatory cytokines include tumor necrosis factor alpha (TNF $\alpha$ ) inducing activation of neutrophils and macrophages as well as chemotaxis. The synthesis of growth factors (colony-stimulating factors), interferon- $\gamma$, interleukins (IL-1, IL-8) prostaglandins tends to increase in macrophages when exposed to TNF $\alpha$. Along with IL-1, TNF $\alpha$ induces the synthesis of acute phase proteins by the cells of mononuclear phagocyte system of the liver. The role of TNF $\alpha$ and IL-1 $\beta$ in the development of fever as pyrogens, which through the bloodstream cross the blood-brain barrier and interact with neurons of the hypothalamus thermoregulation center, has been proved $[10,11]$.

One of the most principal anti-inflammatory biological regulators within multisystem cytokine network of the human body is interleukin-4 (IL-4), which is predominantly produced by Th2-lymphocytes and mainly facilitates suppression of production of TNF- $\alpha$, IL-1 $\beta$, IL-6, IL- 8 by monocytes/macrophages as well as decreased production of IL- 2 , IFN- $\gamma$ and prostaglandins by activated macrophages and Th1-lymphocytes, resulting in weakening of excessive influence of inflammation mediators on the human body and simultaneous activation of humoral body response (increased $\mathrm{IgE}$ and $\mathrm{IgG}$ secretion) [12, 13]. Like other components of cytokine network, IL-4 is a principal factor for implementation of different effector functions which are necessary to maintain cellular homeostasis. The IL-4 basic effector functions consist in stimulation of naive Th0-cells and differentiation of them in Th2-lymphocytes with simultaneous suppression of Th1-cells. Dysregulation of cytokine-mediated mechanisms of cooperation of T-lymphocytes is considered by some scientists as the cause of more severe course of infectious diseases, especially those, that are accompanied by unfavorable outcome $[14,15]$.

\section{Case presentation}

In recent times scientists place greater focus on specific changes in the course of acute enteric infection 
and especially shigellosis in children [14]. Undoubtedly, it can result from a range of factors influencing a child's body: changes of microorganisms' features, family history, ecological changes, present comorbidity and others $[11,14]$. One of the factors affecting the course of shigellosis can be infection of children with Helicobacter pylori (H. pylori) and immune disturbances appearing as a response to inflammation of the gastrointestinal tract mucosa caused by $H$. pylori $[16,17]$. Helicobacter infection is one of the most wide spread among population and it is revealed in $25-80 \%$ of world population depending on age and social and economic level in one or another region $[18,19]$.

Currently a high priority is placed on the peculiarities of immunopathogenesis of diseases including cases of complicated, long-term and chronic course of intestinal infections, so they are extensively involved in both experimental and clinical studies.

Therefore, the scientists stick to the opinion that balanced action of proinflammatory and anti-inflammatory cytokines is of great importance in immunopathogenesis of shigellosis, and concentrations of cytokines in blood serum reflect immune reactions, that occur locally or on the system level and thus can be applied for prognosis of the course of infectious disease as well as for long-term prognosis estimation [12, 13].

However, the response of cytokine system in shigellosis infection was mainly studied due to experimental models and only in specific clinical research [13]. The data concerned with impact of Helicobacter infection on intensity of production of pro- and anti-inflammatory interleukins and, thus, on coordinated and early cytokine response in patients suffering from shigellosis, have not been found in the literature references available.

\section{Aim of research}

Assessment of levels of pro-inflammatory and anti-inflammatory cytokines in shigellosis in children infected with $H$. pylori.

Study of the peculiarity of the reaction of the immune system in children infected with Helicobacter pylori in shigellosis on the basis of assessment of levels of pro- and anti-inflammatory cytokines of blood serum.

\section{Materials and methods}

The study enrolled 113 children aged from 3 months to 3 years, who were hospitalized in Regional children's infectious diseases hospital (Kharkiv) and diagnosed with shigellosis. All children underwent additional examination aimed to detect presence of Helicobacter infection. Presence of $H$. pylori in the stool was detected by means of PCR technique and immunoenzymometric CITO TEST H.Pylori Ag. An assessment of IL-1 $\beta$, TNF- $\alpha$ and IL-4 of the blood serum was provided over time for all children involved in pathological process by means of enzyme-linked immunosorbent assay and reagent kit produced by Vector-Best (Russia).

The children were divided into two groups: Group 1 (37-32.74\%) represented by patients infected with $H$. $p y$ lori and Group $2(76-67.26 \%)$ made up by patients without laboratory markers of Helicobacter infection. The groups were compared according to age (2.2 \pm 1.39 and $1.9 \pm 1.57, \mathrm{p}>0.05)$, sex, premorbid background and severity of shigellosis. In order to compare the content of interleukins of blood serum under study, the control group was made up by 30 apparently healthy children of the same age (from 3 months to 3 years).

Statistical processing of the obtained data was carried out by means of Excel and Statistica 6.0 applications. Statistical analyses were performed using Student's test. A P value of $<0.05$ was considered significant.

\section{Results}

Estimation of the content of interleukins of blood serum in patients with shigellosis in the acute period (day 1-2 of the disease) and in the period of early convalescence (day 5-7) was carried out (Table 1).

Table 1

Level of interleukins of the blood serum in patients in the acute period of shigellosis $(\mathrm{M} \pm \mathrm{m}, \mathrm{ng} / \mathrm{ml})$

\begin{tabular}{|c|c|c|c|}
\hline Cytokines & $\begin{array}{c}\text { Group 1 } \\
(\mathrm{n}=37)\end{array}$ & $\begin{array}{c}\text { Group 2 } \\
(\mathrm{n}=76)\end{array}$ & $\begin{array}{c}\text { Control group } \\
(\mathrm{n}=30)\end{array}$ \\
\hline IL-1 $\beta$ & $11.07 \pm 2.13^{1,3}$ & $18.79 \pm 3.26^{2,3}$ & $5.32 \pm 1.73$ \\
\hline TNF- $\alpha$ & $7.18 \pm 1.23^{1,3}$ & $10.85 \pm 1.32^{2,3}$ & $2,69 \pm 1.67$ \\
\hline IL-4 & $3.53 \pm 1.37$ & $4.64 \pm 1.23$ & $2.06 \pm 0.94$ \\
\hline
\end{tabular}

Note: ${ }^{1}$ - significance of evidence in control group, $p<0.05$;

2 - significance of evidence in control group, $p<0.001$;

${ }^{3}$ - significance of evidence between groups, $p<0.05$

In the acute period of shigellosis, specific features of activated mechanisms of anti-infection protection are observed in all children. The study of concentration of pro-inflammatory IL-1 $\beta$ in blood serum has made it possible to establish that in the acute period of the disease its level in patients of both groups was significantly higher than that one in healthy children $(11.07 \pm 2.13$ in comparison with $5.32 \pm 1.73 \mathrm{ng} / \mathrm{ml}, \mathrm{p}<0.05$ and $18.79 \pm 3.26$ in comparison with $5.32 \pm 1.73 \mathrm{ng} / \mathrm{ml}, \mathrm{p}<0.001$ ). In addition, dependence on present background infection was observed: in the children of Group 2 the concentration of IL-1 $\beta$ was $18.79 \pm 3.26 \mathrm{ng} / \mathrm{ml}$ and it was significantly higher than that one in the patients of Group 1, namely $11.07 \pm 2.13 \mathrm{ng} / \mathrm{ml}(\mathrm{p}<0.05)$.

At the peak of the disease, significantly increased level of TNF- $\alpha$ in comparison with Control group $(7.18 \pm 1.23$ in comparison with $2.69 \pm 1.67 \mathrm{ng} / \mathrm{ml}, \mathrm{p}<0.05$ and $10.85 \pm 1.32$ in comparison with $2.69 \pm 1.67 \mathrm{ng} / \mathrm{ml}$, $\mathrm{p}<0.001$ ) was observed, where the level of pro-inflammatory TNF- $\alpha$ of the patients of Group 2 was significantly higher not only than the same indices of healthy children $(10.85 \pm 1.32$ in comparison with $2.69 \pm$ $\pm 1.67 \mathrm{ng} / \mathrm{ml}, \mathrm{p}<0.001$ ), but also it was different from the indices of Group $1(10.85 \pm 1.32$ in comparison $7.18 \pm$ $\pm 1.23 \mathrm{ng} / \mathrm{ml}, \mathrm{p}<0.05$ ).

Due to the study of IL-4 level in blood serum of children with shigellosis, insignificant increase of the indices in the acute period of the disease was established as well as higher levels of IL-4 content in children without 
background infection in comparison with children infected with $H$. pylori were observed. However, in both cases this difference was not significant $(\mathrm{p}>0.05)$.

Significant difference of IL- $1 \beta$ indices in blood serum of the children of Group 1 and Group 2 (9.65 \pm 0.98 in comparison with $9.06 \pm 1.94 \mathrm{ng} / \mathrm{ml}, \mathrm{p}>0.05)$ as well as by comparison of the indices of Group 2 and Control group $(9.06 \pm 1.94$ and $5.32 \pm 1.73 \mathrm{ng} / \mathrm{ml}, \mathrm{p}>0.05)$ was not revealed (Table 2).

Table 2

Level of interleukins of the blood serum in patients in the period of early convalescence $(\mathrm{M} \pm \mathrm{m}, \mathrm{ng} / \mathrm{ml})$

\begin{tabular}{|c|c|c|c|}
\hline Cytokines & $\begin{array}{c}\text { Group 1 } \\
(\mathrm{n}=37)\end{array}$ & $\begin{array}{c}\text { Group2 } \\
(\mathrm{n}=76)\end{array}$ & $\begin{array}{c}\text { Control group } \\
(\mathrm{n}=30)\end{array}$ \\
\hline IL-1 $\beta$ & $9.65 \pm 0.98^{1}$ & $9.06 \pm 1.94$ & $5.32 \pm 1.73$ \\
\hline TNF- $\alpha$ & $6.37 \pm 0.79^{1}$ & $5.55 \pm 1.13$ & $2.69 \pm 1.67$ \\
\hline IL-4 & $4.06 \pm 1.54^{2}$ & $7.97 \pm 1.13^{2,3}$ & $2.06 \pm 0.94$ \\
\hline
\end{tabular}

Note: ${ }^{1}$ - significance of evidence in control group, $p<0.05$; 2 - significance of evidence between groups, $p<0.05$; ${ }^{3}$ - significance of evidence in control group, $p<0.001$

At the same time, like in the acute period, there is a significant difference of IL-1 $\beta$ levels $(9.65 \pm 0.98$ in comparison with $5.32 \pm 1.73 \mathrm{ng} / \mathrm{ml}, \mathrm{p}<0.05$ ) between the patients of Group 1 and Control group.

TNF- $\alpha$ level in the children without background infection in the period of early convalescence of shigellosis was not characterized by significant difference with the indices of patients with shigellosis infected with pylori (5.55 \pm 1.13 in comparison with $6.37 \pm 0.79 \mathrm{ng} / \mathrm{ml}$, $\mathrm{p}>0.05$ ) and significantly did not differ from the indices of healthy children $(5.55 \pm 1.13$ in comparison with $2.69 \pm 1.67 \mathrm{ng} / \mathrm{ml}, \mathrm{p}>0.05)$. It should be noted that in the period of early convalescence, a substantial difference of TNF- $\alpha$ content in children of Groupl and Control group (6.37 \pm 0.79 in comparison with $2.69 \pm 1.67 \mathrm{ng} / \mathrm{ml}, \mathrm{p}<0.05$ ) present since the peak of the disease, was revealed.

Not quite the same tendencies were established when analyzing IL-4 levels. IL-4 content in blood serum of children with shigellosis without background infection in the period of convalescence turned out to be significantly higher in comparison with apparently healthy children (7.97 \pm 1.13 in comparison with $2.06 \pm 0.94 \mathrm{ng} / \mathrm{ml}, \mathrm{p}<0.001)$ as well as with patients who were infected with $H$. pylori $(7.97 \pm 1.13$ in comparison with $4.06 \pm 1.54 \mathrm{ng} / \mathrm{ml} \mathrm{p}<0.05)$. In children of Group 1, IL-4 content was lower than normal range, however, the difference was not significant (4.06 \pm 1.54 in comparison with $2.06 \pm 0.94 \mathrm{ng} / \mathrm{ml} \mathrm{p}>0.05$ ).

\section{Discussion}

The obtained data are indicative of the fact that in epy acute phase of shigellosis, both groups were char- acterized by increased level of pro-inflammatory IL-1 $\beta$, TNF- $\alpha$ in blood serum, that corresponded to the findings of the previous studies [5, 13], but in patients of Group 2 this increase was more substantial (1.7 times more) and it was significantly different in comparison with patients of Group $1(\mathrm{p}<0.05)$. This tendency has not been considered in literature yet. When the disease was studied over time in the children without background infection, rapid and statistically significant decrease of pro-inflammatory cytokines levels $(\mathrm{p} \leq 0.05)$ was observed like in earlier research [9, 13], while in the children infected with $H$. pylori the increased level of pro-inflammatory cytokines was significantly persisting without substantial decrease of these indices before convalescence period $(p>0,05)$.

In the period of early convalescence, significant increase of IL- 4 content towards the indices of acute period $(\mathrm{p}<0.05)$ was revealed in children without laboratory markers of $H$. pylori. The same findings were also provided by researchers [13]. In the period of early convalescence, the children of Group 2 had significantly higher (1.96 times more) levels of IL-4 of blood serum in comparison with patients with background infection $(p<0.05)$. The absence of significant change of IL-4 content in children of Group 1 in different periods of the disease $(p>0.05)$ was estimated.

Therefore, in children with shigellosis, substantial changes in the system of pro- and anti-inflammatory interleukins are observed. Present infection with H. Pylori has a great impact on the indices of content of pro- and anti-inflammatory interleukins of the blood serum in patients with shigellosis in acute period of as well as at the stages of early convalescence. The findings, which have been obtained, make it possible to deepen the concept of scientists concerned with immune pathogenic mechanisms of development and course of shigellosis in children infected with H. Pylori and afterwards can be the ground for improvement of treatment provided for patients.

\section{Conclusions}

1. The course of shigellosis in young children infected and noninfected with H. Pylori is accompanied by different reactions of cytokine system.

2 . In the acute period of shigellosis, significantly increased content of IL- $1 \beta$, TNF- $\alpha$ is observed in children along with more substantial increase of these indices which is typical for children without background infection with $H$. pylori.

3 . In the period of early convalescence, in children with background $H$. pylori infection, decrease of IL-1 $\beta$, TNF- $\alpha$ to physiological levels is not observed.

4. The course of shigellosis in children infected with $H$. pylori is accompanied by unsubstantial increase of pro-inflammatory IL-4 levels that can be indicative of imbalance in the system of cytokine-mediated mechanisms of inflammation regulation.

\section{References}

1. Kotloff, K. L. Burden and aetiology of diarrhoeal disease in infants and young children in developing countries(the Global Enteric Multicenter Study, GEMS): a prospective, case-control study [Text] / K. L. Kotloff, J. P. Nataro, W. C. Blackwelder, D. Nasrin, T. H. Farag, S. Panchalingam et. al. // Lancet. - 2013. - Vol. 382, Issue 9888. - P. 209-222. doi: 10.1016/s0140-6736(13)60844-2 
2. Wardlaw, T. Diarrhoea: why children are still dying and what can be done [Text] / T. Wardlaw, P. Salama, C. Brocklehurst, M. Chopra, E. Mason // Lancet. - 2010. - Vol. 375, Issue 9718. - P. 870-872. doi: 10.1016/s0140-6736(09)61798-0

3. Farthing, M. Acute Diarrhea in Adults and Children [Text] / M. Farthing, M. A. Salam, G. Lindberg, P. Dite, I. Khalif, E. Salazar-Lindo et. al. // Journal of Clinical Gastroenterology. - 2013. - Vol. 47, Issue 1. - P. 12-20. doi: 10.1097/mcg.0b013e31826df662

4. Adam, P. R. Shigella and Shigellosis [Text] / P. R. Adam, W. D. Picking // Shigella: Molecular and Cellular Biology. Norfolk: Caister Academic Press, 2016. - P. 7-26. doi: 10.21775/9781910190197.01

5. Guarino, A. European Society for Pediatric Gastroenterology, Hepatology, and Nutrition/European Society for Pediatric Infectious Diseases Evidence-Based Guidelines for the Management of Acute Gastroenteritis in Children in Europe [Text] / A. Guarino, S. Ashkenazi, D. Gendrel, A. Lo Vecchio, R. Shamir, H. Szajewska // Journal of Pediatric Gastroenterology and Nutrition. - 2014. Vol. 59, Issue 1. - P. 132-152. doi: 10.1097/mpg.0000000000000375

6. Maldonado, A. Trans-epithelial Communication in the Context of Shigella Infection [Text] / A. Maldonado, B. A. McCormick//Shigella: Molecularand CellularBiology.-Norfolk:CaisterAcademic Press, 2016.-P. 193-210.doi: 10.21775/9781910190197.09

7. Mandal, J. Characterization of Extended-spectrum $\beta$-lactamaseproducing Clinical Isolates of Shigella flexneri [Text] / J. Mandal, V. Sangeetha, D. Nivedithadivya, A. Das, S. C. Parija // Journal of Health, Population and Nutrition. - 2013. - Vol. 31, Issue 3. - P. 405-408. doi: 10.3329/jhpn.v31i3.16834

8. Nikiforov, V. V. Evolution of the etiotropic treatment of shigellosis [Text] // V. V. Nikiforov, M. Z. Shakhmardanov, S. V. Burova, U. N. Tomilin // Medical Council. - 2017. - Vol. 4. - P. 79-80. doi: 10.21518/2079-701x-2017-4-79-80

9. Salgado-Pabon, W. New insights into the crosstalk between Shigella and T lymphocytes [Text] / W. Salgado-Pabon, C. Konradt, P. J. Sansonetti, A. Phalipon // Trends in Microbiology. - 2014. - Vol. 22, Issue 4. - P. 192-198. doi: 10.1016/ j.tim.2014.02.002

10. Cohen, D. Recent trends in the epidemiology of shigellosis in Israel [Text] / D. Cohen, R. Bassal, S. Goren, T. Rouach, D. Taran, B. Schemberg et. al. // Epidemiology and Infection. - 2014. - Vol. 142, Issue 12. - P. 2583-2594. doi: 10.1017/ s0950268814000260

11. Khan, W. Gastrointestinal and Extra-Intestinal Manifestations of Childhood Shigellosis in a Region Where All Four Species of Shigella Are Endemic [Text] / W. Khan, J. K. Griffiths, M. L. Bennish // PLoS ONE. - 2013. - Vol. 8, Issue 5. - P. 64097. doi: 10.1371/journal.pone.0064097

12. Kaluckiy, P. V. Sostoyanie prooksidantnoy sistemy i soderzhanie citokinov u detey pri ostryh kishechnyh infekciyah razlichnoy yetiologii [Electronic resource] / P. V. Kaluckiy, L. Yu. Zayceva, I. G. Hmelevskaya // Sovremennye problemy nauki i obrazovaniya. - 2016. - Vol. 6. - Available at: https://www.science-education.ru/ru/article/view?id=25470

13. Sorokman, T. V. Cytokine Status in Children with Chronic Gastroduodenal Pathology [Text] / T. V. Sorokman, S. V. Sokolnyk, O.-M. V. Popelyuk // Gastroenterology. - 2016. - Vol. 3. - P. 46-49. doi: 10.22141/2308-2097.3.61.2016.79159

14. Sharland, M. Shigellosis [Text] / M. Sharland, K. Butler, A. Cant; M. Sharland (Ed.) // OSH Manual of Childhood Infections: The Blue Book. - Oxford: Oxford University Press, 2016. - P. 819-822. doi: 10.1093/med/9780198729228.003.0113

15. Buslenko, A. O. Citokinovyi profil' kishechnika pri yeksperimental'noy klebsieleznoy infekcii i na fone ee terapii razlichnymi immunomoduliruyushhimi preparatami [Electronic resource] / A. O. Buslenko, A. V. Aleshukina, N. Yu. Pshenichnaya, I. S. Aleshukina, O. D. Kostenko // Sovremennye problemy nauki i obrazovaniya. - 2015. - Vol. 5. - Available at: https://www.science-education.ru/ru/article/view?id=22357

16. Avramenko, A. A. Case of detection of H. pylori infection in all family members during their comprehensive examination [Text] / A. A. Avramenko // Bukovynskyi medychnyi visnyk. - 2016. - Vol. 3, Issue 19. - P. 230-233.

17. Calvet, X. Diagnosis and Epidemiology of Helicobacter pylori Infection [Text] / X. Calvet, M.-J. Ramirez Lazaro, P. Lehours, F. Megraud // Helicobacter. - 2013. - Vol. 18. - P. 5-11. doi: 10.1111/hel.12071

18. Eusebi, L. H. Epidemiology of Helicobacter pylori Infection [Text] / L. H. Eusebi, R. M. Zagari, F. Bazzoli // Helicobacter. - 2014. - Vol. 19. - P. 1-5. doi: 10.1111/hel.12165

19. Koletzko, S. Helicobacter pylori Infection in Children [Text] / S. Koletzko, F. Megraud // Helicobacter Pylori Research. 2016. - Vol. 1. - P. 443-467. doi: 10.1007/978-4-431-55936-8_19

Рекомендовано до публікації д-р мед. наук, професор Ольховська О. М. Дата надходження рукопису 25.04.2017

Nataliia Kurlan, postgraduate student, Department of Pediatric Infectious Diseases, Kharkiv National Medical University, Nauky ave., 4, Kharkiv, Ukraine, 61022

E-mail: ik.natasha@gmail.com 